\title{
Suara Para Gembala Asia tentang Isu Ekologi
}

\author{
Erick Djundjungan Gultom a,1 \\ a Universitas Sanata Dharma, Yogyakarta, Indonesia \\ ${ }^{1}$ erickgultom76@gmail.com
}

\begin{tabular}{|c|c|}
\hline & ABSTRACT \\
\hline & $\begin{array}{l}\text { Today we acknowledge that ecological issues have been widely reported by } \\
\text { various news outlet. Religious organizations have contributed in addressing } \\
\text { these issues through official statements and practical actions, of which Feder- } \\
\text { ation of Asian Bishons' Conferences (FABC) is one of such oranizations. This }\end{array}$ \\
\hline $\begin{array}{l}F A B C \\
\text { ekologi, }\end{array}$ & $\begin{array}{l}\text { paper emphasizes the FABC's involvement to respond the ecological issues. } \\
\text { The review would be conducted by analyzing the documentations released by } \\
\text { FABC from 1972-2016. }\end{array}$ \\
\hline $\begin{array}{l}\text { pemanasan global, } \\
\text { perubahan iklim }\end{array}$ & $\begin{array}{l}\text { The findings are as follows: (i) FABC has been consistently addressing the } \\
\text { issues; (ii) The understanding and response from FABC are in line with the } \\
\text { changing faces of Asia; (iii) to address the issue of ecology, the FABC has ac- } \\
\text { commodated the views of cultures and religious sources in Asia; (iv) FABC's } \\
\text { ecological roles have been summarized into four FABC's orientations on the } \\
\text { ecology. }\end{array}$ \\
\hline
\end{tabular}

\section{PENDAHULUAN}

Buah-buah pemikiran, kepedulian dan pergumulan FABC dalam upayanya mewartakan Kabar Gembira di Asia dan cita-cita FABC untuk menjadikan Gereja semakin membumi di Asia antara lain termuat dalam dokumen-dokumen FABC. Tulisan ini memuat suara para gembala se-Asia tentang isu ekologi sebagaimana dinyatakan dalam dokumen-dokumen FABC. ${ }^{1}$ Tujuannya adalah untuk melihat dinamika pemikiran dan kepedulian FABC dalam menghadapi masalah ekologi dan untuk menyimpulkannya menjadi beberapa poin orientasi ekologis FABC. Namun sebelumnya akan dipaparkan terlebih dahulu mengenai konteks Asia dan keberadaan FABC.

\section{KONTEKS ASIA}

Pada bagian ini penulis memaparkan beberapa kenyataan Asia secara umum. Setiap penggambaran umum atas kenyataan-kenyataan Asia disadari penulis tentulah selalu kurang memadai dan dapat diperdebatkan. Situasi di masing-masing wilayah di Asia dapat begitu kompleks sehubungan dengan berbagai faktor seperti kondisi sosial-politik, latar belakang ras dan etnis dan konteks religio-kultural.

\section{Konteks Politik}

Sebagian besar negara di Asia baru memperoleh kemerdekaannya kurang dari seabad yang lalu seiring dengan berakhirnya era politik kolonial. Negara-negara terse- 
but kemudian berusaha untuk menemukan identitas, ideologi dan struktur politik bagi bangsa mereka masing-masing dan yang sesuai dengan sejarah dan kebudayan mereka sendiri. ${ }^{2}$

Menurut analisis para peserta Sidang Paripurna FABC III, Asia merupakan benua yang ditandai dengan peristiwa-peristiwa politik yang mengguncangkan dan gerakan-gerakan dan transformasi sosial. ${ }^{3}$ Meski demikian, dengan semakin meluasnya pelaksanaan kegiatan pendidikan dan pengetahuan akan prinsip-prinsip demokrasi, negara-negara di Asia saat ini sedang bergerak menuju ke arah politik yang stabil dan masyarakat yang semakin sadar akan hak-hak dan peran politik mereka. Dewasa ini, dapat ditemukan berbagai bentuk ideologi yang mewarnai spektrum politik di Bumi Asia: teokrasi, liberal, sekular, monarki, demokrasi, sosialis, totalitarian, federal, parlemen, presidensial dan sebagainya.

\section{Konteks Ekonomi}

Sebagian besar negara di Asia disebut negara-negara "Dunia Ketiga" dan ditandai dengan kemiskinan yang masif dan rendahnya tingkat kesehatan. ${ }^{4}$ Lebih dari separuh populasi di banyak negara di Asia hidup di bawah garis kemiskinan dan tercabut dari akses untuk mendapatkan barang-barang materi dan sumber-sumber hidup yang mereka perlukan untuk menciptakan kondisi hidup manusia yang seutuhnya bagi mereka sendiri. ${ }^{5}$ Kemiskinan di Asia, menurut FABC, disebabkan oleh struktur-struktur sosial, ekonomi dan politik yang tidak adil terhadap mereka, efek-efek pasca kolonialisme dan feodalisme, introduksi kapitalisme Barat yang membentuk kelas-kelas ke dalam struktur-struktur ekonomi tradisional masyarakat Asia, dan eksploitasi dan pengrusakan sumber-sumber alam dan lingkungan hidup. ${ }^{6}$
Perubahan ekonomi bahkan perubahan sosial di Asia dan di seluruh dunia banyak didorong oleh globalisasi ekonomi. Globalisasi sendiri hanya meningkatkan standar hidup sebagian kecil orang dan menyisakan sejumlah besar lainnya tetap dalam kemiskinan. Konsekuensi lain dari globalisasi adalah urbanisasi berlebihan yang menyebabkan timbulnya tumpukan besar kaum urban dan migrasi, kejahatan dan eksploitasi terhadap mereka yang lebih lemah. ${ }^{7}$ Derap pembangunan yang terlalu memberi penekanan pada bidang ekonomi pada gilirannya akan memberi pengaruh negatif bagi nilai-nilai sosial dan tradisi religius Asia serta mengancam tradisi kultural besar dan ekologi di Asia. ${ }^{8}$

\section{Konteks Sosial}

Bumi Asia terdiri atas beragam ras dan bahasa serta beraneka budaya dan agama yang pada gilirannya menghasilkan struktur sosial yang kompleks pula. Secara umum, kawasan Asia terdiri atas masyarakat agrikutural. Dalam masyarakat agrikultural Asia terdapat perbedaan besar dalam hal luas bidang garapan, metode produksi, pembangunan, dan stratifikasi kasta dan kelas. Sementara itu, kemajuan industri dan teknologi modern telah menghasilkan suatu kelompok sosial baru di Asia, khususnya di daerah urban. Dalam kelompok sosial ini kita juga menemukan mereka yang termasuk kelas atas, kelas menengah dan kelas bawah sesuai dengan tingkat pendapatan mereka.

Masyarakat Asia juga didera oleh berbagai masalah, seperti lonjakan populasi, pengangguran, industrialisasi yang tidak terkontrol, kurangnya perawatan kesehatan dan sistem sanitasi, pekerja anak, eksploitasi terhadap kaum perempuan dan pihak lemah lainnya, keterbatasan pangan, iliter- 
asi, bencana alam dan lain sebagainya. Di waktu yang bersamaan, korupsi merajalela pada semua tingkatan pemerintahan dan kemasyarakatan di banyak negara di Asia. Faktor-faktor ini bermuara pada situasi-situasi konflik, baik di tingkat regional, nasional maupun internasional. ${ }^{9}$

Karakteristik lain yang tampak dalam masyarakat Asia dewasa ini adalah kebangkitan kelompok-kelompok pribumi dan minoritas dan kesadaran mereka akan hak dan peran mereka di dalam masyarakat. Selama berabad-abad mereka telah hidup dalam isolasi sosial, budaya dan politik. Kini mereka mengklaim pengakuan, persamaan hak dan kesempatan. ${ }^{10}$

\section{Konteks Kultural dan Religius}

Beragam definisi telah diajukan para pakar untuk menerangkan arti kebudayaan. Menurut Konsili Vatikan II, secara umum istilah "kebudayaan" dimaksudkan sebagai segala sarana dan upaya manusia untuk menyempurnakan dan mengembangkan pelbagai bakat-pembawaan jiwa raganya. Oleh karena itu mau tak mau kebudayaan manusia mencakup dimensi historis dan sosial, dan istilah "kebudayaan" seringkali mengandung arti sosiologis dan etnologis. ${ }^{11}$ Diterangi oleh deskripsi yang diperoleh dari Konsili Vatikan II dan studi antroplogis dewasa ini, para Uskup Asia menjelaskan kebudayaan seturut empat perspektif dan pendekatan berikut: Budaya sebagai pengolahan (cultivation) roh manusia; kebudayaan sebagai hasil pemahaman empiris; kebudayaan sebagai ekspresi simbolik; dan pemahaman masyarakat sebagai realitas kebudayaan. ${ }^{12}$ Keempat perspektif dan pendekatan kebudayaan ini bersifat komplementer. Kita dapat menyimpulkan bahwa kebudayaan jelas merupakan jalan konkrit menjadi manusia yang ditempuh oleh masyarakat, kelompok, atau bangsa tertentu.

Kebudayaan dan masyarakat merupakan dua hal yang saling terkait dan tidak dapat terpisahkan. Manusia merupakan makhluk sosial dan dari masyarakatlah ia memperoleh kebudayaannya. Kebudayaan Asia yang ada sekarang ini merupakan hasil dari penggabungan kebudayaan berbeda dari masyarakat berbeda yang terjadi selama ratusan tahun. Beberapa kebudayaan yang paling berpengaruh adalah kebudayaan India, Cina, dan Arab. ${ }^{13}$ Di Bumi Asia juga eksis sejumlah suku dan kelompok kebudayaan kecil yang tetap memelihara warisan kebudayaan dan identitas mereka. Kebudayaan Asia di era modern juga dipengaruhi oleh kebudayaan Barat dan Kristianitas.

\section{MENEROPONG KE DALAM FABC}

Berdirinya FABC merupakan tonggak bersejarah bagi umat Kristiani di Asia. Cikal-bakal pembentukan FABC bermula pada sidang bersejarah 180 Uskup Asia di Manila di akhir bulan November 1970. Sebagai hasil sidang tersebut, pada tanggal 19 November 1970, para Uskup mengesahkan sebuah dokumen berjudul "Pertemuan Para Uskup Asia: Pesan dan Resolusi Para Uskup Asia”. Dalam dokumen ini mereka antara lain menguraikan aneka tinjauan atas wajah-wajah Asia dan menyatakan ingin dapat lebih sungguh berbakti kepada bangsa-bangsa Asia. Para Uskup menyebutkan bahwa umat Katolik Asia berkeinginan -sebagai persekutuan-persekutuan Katolik- untuk semakin terintegrasi dalam persekutuan-persekutuan yang lebih besar di sekitarnya, dan secara kultural menjadi bagian dari Asia yang -meski perlahan namun pasti- akan lahir di saat ini. ${ }^{14}$ 
Kelahiran Federasi semakin mendekati kenyataan berkat salah satu resolusi sidang yang mendesak untuk segera membentuk suatu struktur yang permanen. ${ }^{15}$ Sebagai langkah lanjutan dari hasil sidang tersebut kemudian diadakanlah sebuah pertemuan di Hong Kong pada tanggal 24-25 Agustus 1972 yang bertujuan untuk menyusun suatu statuta FABC. Statuta yang dihasilkan selanjutnya diserahkan kepada Takhta Suci untuk mendapatkan persetujuan. Akhirnya, pada tanggal 16 November di tahun yang sama, Takhta Suci mengabulkan pengesahan atas statuta tersebut sekaligus menandai berdirinya FABC secara resmi. Konferensi-Konferensi anggota Federasi kala itu adalah Bangladesh, India-Nepal, Indonesia, Jepang, Korea, Laos-Kamboja, Malaysia-Singapura-Brunei, Myanmar, Pakistan, Filipina, Sri Lanka, Thailand, dan Vietnam. Kawasan gerejawi Hongkong dan Makau bergabung juga sebagai anggota luar biasa. Dewasa ini, FABC beranggotakan sembilan belas Konferensi Episkopal, dan delapan anggota luar biasa. ${ }^{16}$

\section{SIFAT, FUNGSI, DAN STRUKTUR ORGANISASI FABC ${ }^{17}$}

FABC merupakan sebuah asosiasi sukarela dari Konferensi-Konferensi Episkopal di Asia yang ditetapkan melalui persetujuan Takhta Suci. Tujuan FABC adalah guna memperkuat di antara anggota-anggotanya rasa solidaritas dan saling bertanggung jawab atas kesejahteraan Gereja dan masyarakat di Asia. Keputusan-keputusan yang diambil oleh FABC bersifat memiliki daya yuridiksi yang tidak mengikat; penerimaan atas keputusan-keputusan tersebut merupakan ekspresi dari tanggung jawab kolegial.

Fungsi FABC diuraikan dalam tujuh poin berikut: pertama, FABC bermaksud untuk mempelajari cara dan sarana mempromosikan kerasulan, khususnya dalam terang Konsili Vatikan II dan dokumen-dokumen resmi pasca Konsili, dan seturut kebutuhan Asia. Kedua, FABC bekerja untuk membuat kehadiran dinamis Gereja semakin intensif dalam pembangunan yang menyeluruh bangsa-bangsa Asia.

Fungsi FABC berikutnya adalah membantu mempelajari masalah-masalah yang menjadi perhatian umum Gereja Asia dan untuk menyelidiki kemungkinan-kemungkinan solusi dan tindakan terkoordinasi. Keempat, untuk memajukan inter-komunikasi dan kooperasi di antara Gereja-Gereja lokal dan para Uskup Asia. Berikutnya, FABC juga berfungsi untuk menyediakan pelayanan bagi Konferensi-Konferensi Episkopal di Asia dengan tujuan membantu mereka memahami dengan lebih baik kebutuhan-kebutuhan umat Allah.

Keenam, FABC berfungsi memperkuat pembangunan organisasi-organisasi dan gerakan-gerakan yang lebih tertata di dalam Gereja pada tingkat internasional. Fungsi FABC yang ketujuh adalah untuk memperkuat komunikasi dan kerja sama ekumenis dan interreligius.

FABC melaksanakan fungsi-fungsinya melalui suatu struktur hierarki yang terdiri dari Sidang Paripurna, Komite Sentral, Komite Kerja, dan Sekretariat Pusat. Sidang Paripurna merupakan badan tertinggi dalam FABC yang terdiri dari seluruh ketua atau presiden Konferensi-Konferensi Episkopal anggota FABC atau perwakilannya yang ditunjuk secara resmi, Uskup-Uskup yang diutus baik oleh masing-masing Konferensi yang menjadi anggota FABC, oleh anggota-anggota luar biasa maupun oleh Komite Kerja. Sidang Paripurna bertemu setiap empat tahun. Federasi juga didukung oleh sem- 
bilan kantor atau agensi yang masing-masing menangani bidang kehidupan Gereja dan masyarakat tertentu, yakni untuk urusan evangelisasi, pendidikan dan pamong mahasiswa, komunikasi sosial, hubungan ekumenis dan interreligius, awam dan keluarga, kajian teologi, pengembangan manusia, hidup religius, dan urusan imam.

\section{Orientasi FABC $^{18}$}

Orientasi FABC adalah dialog. Latar belakang dialog menjadi orientasi FABC berawal dari kesadaran akan ironi bahwa Gereja-Gereja setempat di Asia masih bersifat asing bagi para penduduknya. Hal ini bukan melulu disebabkan karena agama Kristiani dibawa masuk dari luar benua ini atau karena ia menghadirkan iman yang berbeda. Pada kenyataannya, bangsa-bangsa di Asia selalu menerima dan memelihara keragaman. Anggapan "agama yang asing” yang disematkan kepada agama Kristiani timbul terutama karena Gereja-gereja setempat tidak berhasil menyatu dengan rakyat. Sekalipun ada banyak sumbangan Gereja di bidang amal-kasih yang patut dipuji, pada umumnya Gereja-Gereja ini menjaga jarak terhadap arus utama kehidupan rakyat, sejarah, perjuangan-perjuangan dan impian-impian mereka.

FABC menginginkan agar Gereja menjangkau dan menyentuh hati rakyat dengan memasuki dialog dengan aneka agama di Asia, berbagai budaya di Asia, serta kaum miskin yang merupakan mayoritas di Asia. Dengan demikian diharapkan Gereja dapat makin berakar di tanah Asia. Kebudayaan dan tradisi religius yang majemuk, dan massa kaum miskin yang besar merupakan tiga realitas Asia yang tampak mencolok. FABC dalam membangun dialog dengan masyarakat Asia mau tidak mau selalu berhadapan dengan ketiga kenyataan ini. Para Uskup dalam sidang paripurna I FABC pada tahun 1974 telah menyatakan komitmen mereka untuk semakin membumikan Kabar Gembira dan semakin terlibat dalam perihidup bangsa-bangsa Asia dengan melaksanakan dialog rangkap tiga atau triple dialogue: dialog dengan kebudayaan-kebudayaan, tradisi-tradisi religius, dan massa kaum miskin Asia.

FABC menjadi pelopor dalam penyelenggaraan program-program exposure bagi para Uskup. Para Uskup menggali sebab-musabab paling mendalam atas kenyataan-kenyataan sosio-politik, situasi-situasi ketidakadilan, pelanggaran martabat dan hak-hak manusiawi, dan mencanangkan untuk membongkar sebab-sebab sitematis kemiskinan, penghisapan dan ketidak-adilan. Mereka mengakui pentingnya analisis sosial yang diintegrasikan ke dalam kebijakan-kebijakan pastoral Gereja.

Para Uskup Asia memaknai evangelisasi sebagai penempatan Injil beserta daya kekuatannya secara dinamis ke dalam kenyataan-kenyataan Asia melalui proses dialog dan transformasi dalam kesinambungan dengan tradisinya. Upaya mencapai cita-cita ini membutuhkan perubahan-perubahan yang memadai di dalam komunitas-komunitas Kristiani, baik di tingkat struktural maupun di tingkat pelayanan. Sebagai contoh, para Uskup telah berulang kali merekomendasikan pembentukan komunitas-komunitas basis yang dapat memfasilitasi penghayatan Injil sehari-hari, tampilnya pelbagai karisma umat beriman, dan pelaksanaan kepemimpinan yang partisipatif.

\section{PERNYATAAN EKOLOGIS FABC}

Sejak awal berkumpul dan berbagi pengalaman di Manila pada tahun 1970, para gembala umat beriman di Asia berkeinginan 
untuk semakin melayani bangsa Asia dan membela martabat manusia. Di tengah realitas wajah Asia yang berubah-ubah, mereka berkomitmen agar umat beriman di Asia makin berintegrasi dengan komunitas-komunitas yang lebih luas di kawasan ini dan semakin memperjuangkan setiap hal yang menyangkut martabat manusia. Dengan terbentuknya FABC pada tahun 1972, para Uskup Asia telah memiliki wadah untuk mewujudkan komitmen mereka tersebut.

FABC berfungsi antara lain sebagai wadah untuk mempelajari cara dan sarana mempromosikan kerasulan seturut kebutuhan Asia agar kehadiran dinamis Gereja semakin intensif dalam pembangunan menyeluruh bangsa-bangsa Asia. Selain itu FABC juga berfungsi untuk membantu mempelajari masalah-masalah yang menjadi perhatian umum Gereja Asia dan menyelidiki kemungkinan-kemungkinan solusi dan tindakan terkoordinasi; untuk menyediakan pelayanan bagi konferensi-konferensi episkopal di Asia dengan maksud membantu mereka memahami dengan lebih baik kebutuhan-kebutuhan umat Allah.

Sidang Paripurna yang dilaksanakan empat tahun sekali merupakan badan tertinggi dalam FABC. Sejak FABC berdiri hingga tahun 2016, Sidang Paipurna telah terlaksana sebanyak sebelas kali dan mengambil tempat di berbagai kota di Asia termasuk di kota Bandung, Indonesia yakni Sidang Paripurna V FABC tahun 1990. Berbagai tema telah diangkat dan direfleksikan bersama oleh para peserta Sidang Paripurna. Satu hal yang sama dalam setiap kali mereka bersidang adalah mengawalinya dengan melihat kenyataan atau realitas yang tengah terjadi di Asia. Beragam realitas Asia di tengah wajah Asia yang terus berubah disaksikan dan dialami para perserta sidang, baik berupa harapan dan tantangan. Salah satu tantangan realitas Asia yang menjadi sorotan FABC adalah masalah ekologi. Berikut ini adalah dinamika pergumulan FABC dalam menanggapi tantangan isu ekologi.

\section{Periode 1970-1991}

Dalam periode ini, masih sedikit ditemukan penggunaan istilah maupun pembahasan tentang ekologi. Meski demikian tiga dokumen awal dalam periode ini memegang peranan penting dalam memberikan landasan pemahaman dan kerangka kerja bagi pembahasan berbagai tantangan Gereja-Gereja Asia yang muncul kemudian.

Pada pertemuan di Manila tahun 1970 dan sidang paripurna di Taipei pada tahun 1974, para Uskup mengarahkan pandangan kepada tugas Gereja di dunia Asia. Dalam dokumen "Pertemuan Para Uskup Asia" ditegaskan bahwa umat beriman di Asia ingin makin berintegrasi dengan persekutuan-persekutuan yang lebih luas di kawasan ini, semakin melayani bangsa Asia dan dengan kesungguhan hati menyanggupi akan memperjuangkan setiap hal yang menyangkut martabat manusia. Melalui dokumen "Evangelisasi di Masa Modern Asia" (FABC I) para Uskup antara lain menyatakan bahwa mewartakan Injil di Bumi Asia adalah tugas Gereja yang penting dan mendesak. Pewartaan Injil di Asia dilakukan melalui dialog rangkap tiga, yakni dialog dengan budaya dan agama yang majemuk di Asia dan dengan aum miskin yang dominan di Asia. Benih perhatian para Uskup terhadap isu ekologis mulai tampak dalam sidang paripurna ini melalui pernyataan komitmen mereka untuk memperhatikan secara khusus nasib kaum buruh dan petani dan untuk membantu menjamin kebutuhan-kebutuhan pokok semua orang. Selanjutnya sidang paripurna II di Kalkuta pada tahun 1978 membantu 
para Uskup menyadari bahwa doa dan kehidupan batin merupakan faktor-faktor yang sungguh diperlukan dalam menghadapi tantangan-tantangan yang amat berat di benua Asia.

Istilah "ekologi" muncul pertama kali dalam dokumen "Gereja -Sebuah Persekutuan Iman di Asia" (FABC III tahun 1982). Dalam salah satu resolusi yang dihasilkan disebutkan: "FABC hendaknya mengecam perlombaan senjata antar bangsa, peningkatan percobaan-percobaan nuklir, dan pembuangan limbah nuklir yang membahayakan bagi keseimbangan ekologi di negara-negara Asia."19 Masalah ekologi dalam bentuk eksploitasi lingkungan dan kesempatan mengakses sumber daya alam menjadi sorotan FABC saat mencermati ketidakadilan dan kemiskinan yang masih terus di alami oleh bangsa-bangsa Asia. ${ }^{20}$

Meski menemukan tantangan ekologi dalam kenyataan di Asia, para Uskup juga menyaksikan banyak tanda harapan yang menggembirakan dalam masalah-masalah perubahan sosial dan ketidakadilan yang merajalela. ${ }^{21}$ Dialog antara tradisi-tradisi keagamaan, gerakan lingkungan hidup, dan berbagai aspek gerakan kaum perempuan menimbulkan harapan akan corak hidup rohani yang lebih holistik. Hasrat kerohanian, kontemplasi, kepedulian akan lingkungan hidup, sikap hormat terhadap kaum perempuan, semuanya itu merupakan tanda-tanda harapan yang agung. Di samping itu juga disadari realitas ketidakadilan di Asia yang tidak berubah antara lain kemiskinan massal, akses tidak merata terhadap sumber-sumber daya alam, dan eksploitasi lingkungan. ${ }^{22}$

Selain dokumen-dokumen di atas perlu juga disebutkan di sini hasil studi bersama para Uskup Asia yang tergabung dalam Insti- tut para Uskup untuk Urusan Hubungan Interreligius atau Bishops' Institute for Religius Affairs (BIRA). BIRA telah melaksanakan dua belas kali pertemuan yang membahas tentang teologi dialog. Dalam pertemuannya yang ke sebelas dan dua belas di antaranya menyatakan bahwa nasib umat manusia berkaitan erat dengan cara mereka mengolah Bumi. Menurut para Uskup, harmoni dan damai membutuhkan sikap menghormati Bumi. ${ }^{23}$ Lebih lanjut para Uskup menegaskan bahwa sikap menghormati alam dan mengasihi semua yang hidup ditemukan dalam agama-agama dan tradisi-tradisi kultural Asia. Hidup dan kesaksian umat beriman seharusnya menampakkan sensitivitas yang lebih besar terhadap alam. ${ }^{24}$ Kemudian dalam penutup rangkaian studi tentang dialog ini para Uskup kembali menegaskan bahwa tradisi-tradisi religius mengakui kekudusan alam dan mengundang kita hidup dalam harmoni dengan alam dan memperkuat pertumbuhannya. ${ }^{25}$

Pembahasan FABC atas tema ekologi sebagaimana ditemukan dalam dokumen-dokumen hasil sidang paripurna dalam periode 1970-1991 lebih banyak berbicara mengenai potensi masalah ekologis dan beberapa bentuk masalah ekologis sebagai bentuk ketidak adilan yang dialami masyarakat Asia. Para Uskup melihat ketidakadilan ini sebagai salah satu tantangan yang harus disikapi oleh FABC sesuai dengan komitmen mereka untuk semakin berintegrasi dengan masyarakat Asia dan melayani mereka. Menjelang akhir periode ini barulah para Uskup -melalui dokumen BIRA IV/11 tahun 1988merekomendasikan tindakan nyata kepada umat kristiani di Asia supaya bekerjasama dengan semua pihak yang berkehendak baik untuk menjaga keseimbangan dan harmoni ekosistem dan melindungi alam beserta kekayaannya dari perusakan. ${ }^{26}$ 


\section{Periode 1992-2016}

Selama periode 1992-2016 FABC telah mengadakan enam kali sidang paripurna. Tema ekologi menjadi bagian pembahasan dalam setiap sidang tersebut. Sidang Paripurna FABC VI 1995 menyebutkan bahwa ekologi merupakan salah satu dari lima area pastoral besar dalam kerangka pemuridan. Sebagai murid-murid Kristus yang memilih kehidupan, kita perlu menimbang dan bertindak bersama dengan mereka yang beriman lain dan dengan kelompok-kelompok lainnya untuk melawan daya-daya yang merusak ekologi. ${ }^{27}$ Refleksi para Uskup tentang tema kemuridan menghasilkan suatu visi kehidupan yang holistik. Kehidupan yang holistik buah pengembangan otentik setiap dan seluruh manusia untuk mengalami harmoni dan kedamaian batin dan memasukkan unsur etis ke dalam seluruh ciptaan. ${ }^{28}$

Saat merefleksikan pembaruan Gereja sebagai bentuk misi kasih dan pelayanan (sidang paripurna VI), para Uskup menjumpai lima masalah dan tantangan dalam misi kasih dan pelayanan yang memerlukan perhatian pastoral istimewa, yakni: globalisasi, fundamentalisme, situasi politik, ekologi, dan militerisasi. ${ }^{29}$ Saat melihat pembangunan yang sedang digalakkan di Asia dan dampaknya terhadap lingkungan, para Uskup menyaksikan kerusakan lingkungan yang terus terjadi sebagai akibat dari polusi yang tidak terkontrol, meningkatnya kemiskinan, deforestasi dan sebagainya. Dampak kerusakan lingkungan hidup semakin parah manakala beberapa negara di Asia menjadi tempat pembuangan limbah beracun, menjadi panggung produksi industri-industri yang berbahaya dan tidak memiliki standar-standar lingkungan sama sekali terhadap hasil-hasil industri. ${ }^{30}$ Perhatian pastoral istimewa kepada masalah dan tantangan ekologi menjadi salah satu perwujudan misi kasih dan pelayanan Gereja. ${ }^{31}$

Degradasi lingkungan hidup di Asia juga berdampak negatif terhadap keluarga-keluarga di Asia. Masalah ekologis ini menjadi salah satu tantangan yang dihadapi keluarga-keluarga di Asia dalam membawa keluarga Asia menuju suatu budaya hidup yang integral. Budaya hidup integral menjadi hasil refleksi para Uskup dalam sidang paripurna VIII sebagai spiritualitas yang dibutuhkan keluarga di Asia dalam mewujudkan identitas dan menunaikan misi mereka. ${ }^{32}$ Sebagai gerakan transformasi sosial, budaya hidup integral menjadi sumbangan berharga dalam menghadapi krisis lingkungan hidup yang tengah terjadi.

Sorotan FABC terhadap isu ekologi terus berlanjut ke dalam Sidang Paripurna FABC IX tahun 2009 yang mengangkat tema Ekaristi. Berangkat dari refleksi tentang cara semakin menghidupi Ekaristi di Asia, para Uskup tiba pada tanda-tanda harapan dalam dunia yang tidak adil melalui peristiwa Ekaristi itu sendiri. Ekaristi membuka mata kita untuk memandang keberadaan alam sebagai suatu karunia. Menghidupi Ekaristi mendorong kita mendapatkan kembali visi ini. Di Asia, sebagaimana di banyak tempat lain di dunia, pola pikir komoditas telah menggantikan pola pikir karunia. Ekaristi memulihkan kepercayaan kepada Sang Pencipta dan rasa hormat terhadap ciptaan sebagai karunia Allah, bukan sebagai komoditi yang dimanipulasi demi tujuan-tujuan konsumeris. Sikap tidak hormat kepada ciptaan akan membawa kepada kehancuran dan kematian. Ciptaan barulah sungguh menjadi tanda hidup dan cinta Pencipta bila kita memiliki kesadaran akan keberadaan ciptaan sebagai karunia ilahi. Para Uskup melihat bahwa wujud kepedulian yang mendesak 
bagi Gereja-Gereja Kristen adalah membawa penatalayanan ciptaan ke dalam inti spiritualitas dan kemuridan Kristen. ${ }^{33}$ Akhirnya para Uskup memberi beberapa rekomendasi pastoral, salah satunya adalah menganjurkan konferensi-konferensi episkopal dan keuskupan-keuskupan untuk mengadakan program-program pastoral dalam hal penatalayanan ciptaan. ${ }^{34}$ Di sini, FABC telah melangkah maju dengan merefleksikan seluruh ciptaan dalam terang iman. Dengan kata lain, selain masalah moral dan etis, FABC kini memandang tantangan ekologis juga sebagai masalah religius.

Peserta Sidang Paripurna X FABC di tahun 2012 dengan tegas menyebutkan ekologi sebagai salah satu kecenderungan besar atau mega-trend di Asia: ${ }^{35}$ para Uskup telah melihat bahwa persoalan ekologis saat itu sudah berkenaan dengan suatu masalah yang jauh lebih mendesak dan merusak, yaitu pemanasan global dan perubahan iklim. Seluruh dunia telah mengalami tanda-tanda perubahan iklim yang mendatangkan malapetaka.

Para Uskup di Asia telah menjadi semakin sadar dan peduli dengan masalah ekologi dan implikasi etisnya. Mereka juga menyaksikan di Gereja-Gereja lokal sudah bekerja sama dengan masyarakat sipil untuk peduli kepada keutuhan ciptaan. ${ }^{36}$ Dengan begitu, kesadaran, kepedulian dan tindakan atas tantangan ekologis ini juga tengah di bawa hingga ke tingkat akar rumput. ${ }^{37}$ Melalui sidang paripurna ini, pemahaman FABC tentang isu ekologi mengalami perkembangan yakni perubahan iklim dan pemanasan global yang dialami oleh semua orang di muka Bumi. Di satu sisi FABC terus mengupayakan pemeliharaan keutuhan ciptaan, namun kini telah disadari masalah lain yang lebih mendesak yakni perubahan iklim dan pemanasan global sebagai masalah makro dan masalah akan kebutuhan keadilan intergenerasi.

Sidang paripurna XI FABC tahun 2016 menjadi sidang paripurna terkini. Pembahasan tema keluarga di dalamnya membuahkan gagasan menarik, yakni mengajak keluarga beriman di Asia -bersama dengan keluarga-keluarga dari agama-agama lainnya- menunjukkan kepedulian mereka dalam menghadapi kenyataan perubahan iklim dan pemanasan global. Kepedulian ini hendak dilakoni dengan mengedepankan gaya hidup sederhana. Gaya hidup sederhana merupakan salah satu panggilan Roh Kudus yang dapat ditanggapi langsung dengan mudah. Gagasan ini menjadi buah refleksi para Uskup yang memandang krisis ekologis sebagai masalah moral, religius dan masalah bersama semua orang.

Hasil keputusan dan rekomendasi sidang paripurna FABC sebagai badan otoritas tertinggi dalam FABC selanjutnya diterjemahkan oleh unit kerja dan kantor-kantor di bawahnya. Sehubungan dengan masalah ekologi, FABC memiliki unit kerja khusus yakni Unit Kerja Perubahan Iklim atau Climate Change Desk (CCD) FABC. Unit kerja ini terbentuk setelah FABC menggelar seminar Perubahan Iklim I di tahun 2011. Selain itu, rekomendasi FABC untuk membangun suatu spiritualitas ekologis juga telah diupayakan oleh Kantor Urusan teologi atau Office of Teological Concern (OTC) FABC dengan melaksanakan studi dan refleksi untuk mengeksplorasi suatu pendekatan Kristiani di Asia dalam menghadapi masalah ekologi.

Dalam Seminar Perubahan Iklim I tahun $2011^{38}$, para peserta bertukar informasi tentang realitas perubahan iklim yang mereka saksikan. Selanjutnya mereka melakukan 
refleksi iman tentang hal ini dengan menggunakan teks biblis mengenai penciptaan dan kedosaan dari kitab Kejadian sebagai titik berangkat permenungan. Permenungan ini berujung pada peristiwa Paskah dalam mana Yesus menjadi pendamaian kita, menjadi damai dan harmoni bagi dunia. Ia telah memperbaiki ketidak adilan dan memulihkan segala sesuatu dengan diri-Nya sendiri. Dalam terang refleksi iman inilah para peserta seminar melihat dimensi-dimensi religius dan etis perubahan iklim dan ancaman yang ditimbulkannya bagi umat manusia. Refleksi ini berbuah kesepakatan bahwa pastoral di bidang ekologi merupakan kebutuhan yang mendesak dan Gereja hendak menghadapi iklim global pada hari ini dan untuk generasi mendatang dengan berpihak kepada mereka yang miskin. Untuk semua ini para peserta seminar meminta FABC untuk segera membentuk sebuah agensi atau unit kerja perlindungan iklim.

Suatu pendekatan Kristiani dalam menghadapi masalah ekologi telah dipayakan oleh para teolog OTC FABC melalui studi mereka di tahun 2012. ${ }^{39}$ para teolog ini mengalawinya dengan melihat kenyataan krisis lingkungan di Asia dan sumber-sumber Asia, yakni tradisi-tradisi religius, eko-spiritualitas pribumi, dan spiritualitas eko-feminisme. Dari sini mereka kemudian beranjak kepada pemetaan masalah ekologi dari sudut pandang biblis dan teologis. Sebagai landasan biblis, para teolog mengawali refleksi mereka dari Kitab Kejadian. Selanjutnya teologi tentang ciptaan berupaya mereka bangun dengan memperhatikan beberapa dimensi seperti: teologi trinitaris, kristologis, pneumatologis, kosmis, antropologis dan etis.

Refleksi para teolog OTC bermuara pada empat kepedulian teologis yakni kepedulian akan penatalayanan, akan keadilan dan amal kasih, akan relasi komunal, dan akan kontinuitas kosmos.

Seminar Perubahan Iklim II $^{40}$ di tahun 2013 menjadi kelanjutan upaya FABC dalam menanggapi isu perubahan iklim. Fokus pembahasan dalam seminar kali ini adalah dampak dan tanggapan Asia terkait dengan isu perubahan iklim. Langkah maju ditempuh para peserta seminar dengan mendengarkan penjelasan dari para ahli di bidang iklim. Sumbangsih penting dari kegiatan ini antara lain ditemukan dalam identifikasi prioritas Gereja Asia dalam memberikan tanggapan atas krisis perubahan iklim, yakni: mendorong semua umat beriman untuk melakukan refleksi kritis atas isu perubahan iklim sebagai masalah keadilan dan religius, meminta Gereja membantu masyarakat menyadari eksploitasi alam merupakan bentuk tindakan melawan Allah, meminta Gereja memajukan model-model yang memadukan ilmu pengetahuan dengan aksi komunitas, meminta Gereja menjawab kebutuhan umat saat ini yakni menghidupi eko-spiritualitas yang selaras dengan Sabda Allah dan berpihak kepada kaum miskin, dan meminta Gereja memanfaatkan keluasan jangkauannya terhadap masayarakat sipil untuk membangkitkan pendapat publik dan gaya hidup yang lebih fokus pada menjadi (being) -bukan sekedar memiliki (having).

Demikianlah rangkuman pernyataan FABC dalam menanggapi masalah ekologi. Berangkat dari temuan-temuan di atas, penulis selanjutnya akan menyimpulkannya menjadi beberapa poin orientasi ekologis FABC.

\section{ORIENTASI EKOLOGIS FABC}

Masalah ekologis terus terjadi di Bumi Asia dan berkembang menjadi krisis ekologi dan lingkungan hidup. Dewasa ini bahkan 
seluruh dunia mengalami krisis ekologi dan lingkungan hidup dalam bentuk perubahan iklim atau pemanasan global. FABC telah melakukan refleksi iman guna menentukan sikap, tanggapan dan tindakan konkrit Gereja Asia atas tantangan ekologi ini. Pembahasan mengenai tantangan ekologi dilakukan baik oleh sidang paripurna maupun dalam pertemuan-pertemuan yang diadakan oleh agensi-agensi dalam FABC. Dari dinamika tema ekologi yang telah dilalui FABC dapat disimpulkan beberapa hal berikut ini. Pertama, FABC merupakan salah satu pihak yang telah dengan konsisten menyatakan perhatian dan keprihatinannya berkenaan dengan isu ekologis di Asia. Meski Unit Kerja Perubahan Iklim (CDD) FABC baru dibentuk pada tahun 2014, FABC telah mulai menyuarakan keprihatinannya secara resmi sejak tahun 1982, yakni melalui Pernyataan Sidang Paripurna III di Bangkok, Thailand.

Kedua, kiprah ekologis FABC telah penulis cermati sejak berdirinya FABC di tahun 1972 hingga 2016. Selama kurun waktu ini penulis melihat terdapat dinamika pemahaman dan pembahasan terkait isu ekologi di dalam federasi. Perkembangan pemahaman dan pergumulan federasi ini terjadi seturut kenyataan yang dijumpainya, baik di lokal Asia maupun di skala global. Isu ekologis dalam kacamata FABC bermula dari keprihatinan para Uskup atas perlombaan senjata dan limbah nuklir yang mengancam keseimbangan ekosistem di Asia. Dalam perkembangannya, FABC melihat isu ekologis dalam bentuk eksploitasi alam yang merusak sumberdaya alam dan dalam bentuk ketidakmerataan hak mengakses sumber-sumber alam. Di sini FABC menyaksikan isu ekologis sebagai masalah ketidakadilan. Dalam pandangan FABC, kaum miskin yang berjumlah besar di Asia menjadi pihak yang paling menderita akibat degradasi ekologis dan perubahan iklim yang tengah terjadi.

Selanjutnya, FABC menyadari bahwa rusaknya sumber daya alam, selain berakibat buruk bagi kehidupan manusia saat ini, juga berdampak buruk bagi generasi mendatang. Ada masalah intergenerasi dalam persoalan ekologis yang tengah dihadapi. Selain itu, mewariskan Bumi yang rusak dan yang tidak dapat dihidupi oleh generasi mendatang juga merupakan pelanggaran atas perintah Allah untuk tidak mencuri. Kepedulian Gereja terhadap kelestarian ciptaan merupakan bentuk ekspresi dari kepedulian Allah sendiri. Suara Allah yang tampak di tengah dunia dan dalam penderitaan kaum miskin perlu mendapat perhatian dan tanggapan. Dengan demikian, selain terkait dengan etis dan moral, ada masalah religius dalam persoalan ekologis.

FABC kemudian menyaksikan bahwa kegiatan menguras kekayaan alam yang terus terjadi secara luas dengan tidak mengindahkan keadilan dan tanggung jawab pada gilirannya menghasilkan masalah-masalah seperti beragam bencana alam yang makin sering terjadi, meningkatnya arus pengungsi akibat bencana alam, dan pengembangan industri pariwisata yang tak ramah lingkungan. Dan yang terkini, di tengah upaya mengedepankan pengembangan lestari, memelihara harmoni dan keutuhan ciptaan, FABC sejak tahun 2012 menyadari isu ekologis lain yang lebih serius yakni perubahan iklim dan pemanasan global.

Ketiga, dalam menanggapi isu ekologis, FABC mengawali refleksi mereka dengan menyaksikan realitas situasi pastoral di Asia. Pemahaman akan realitas ini menjadi landasan FABC dalam telaah selanjutnya. Gambaran situasi pastoral Asia diperoleh 
di antaranya melalui dialog dengan "sumber-sumber Asia" yakni agama-agama dan budaya-budaya. Seperti telah diuraikan dalam bab ini, FABC telah mengakomodasi pandangan agama Islam, Budha, Hindu, Konghucu, Tao, serta eko-spiritualitas pribumi dan spiritualitas eko-feminisme.

Keempat, ada empat orientasi ekologis FABC yang dapat penulis simpulkan setelah mempelajari kiprah FABC berkenaan dengan tantangan isu ekologis: (i) masalah ekologis merupakan masalah moral dan religius; (ii) sumber-sumber realitas Asia perlu diajak berdialog dalam menjawab tantangan isu ekologis di Asia; (iii) semua orang bertanggung jawab mengupayakan pengembangan lestari, memelihara harmoni dan keutuhan ciptaan; (iv) tanggung jawab tersebut diwujudnyatakan melalui pengembangan manusiawi yang holistik dan pengembangan spiritualitas ciptaan.

\section{Masalah Ekologis Bercorak Moral}

Ancaman terhadap keseimbangan ekologi menjadi awal perhatian para Uskup dalam hal ekologi. Selanjutnya pemahaman persoalan ekologis sebagai masalah keadilan muncul dalam refleksi para peserta Sidang Paripurna V FABC tahun 1990 yang membahas tentang perjalanan bersama menuju milenium ketiga. Mereka menilai masalah eksploitasi lingkungan merupakan salah satu bentuk pelanggaran terhadap keadilan yang masih terjadi di Bumi Asia. Kemiskinan massal yang masih menjadi kenyataan dominan di Asia menyebabkan ratusan juta orang tidak memiliki akses terhadap sumber daya alam. Ketidakadilan ini masih diperparah oleh eksploitasi lingkungan yang telah menghancurkan aneka ragam sumber daya alam yang amat berharga, dan dengan demikian menghancurkan hidup rohani sebagian besar masyarakat Asia. ${ }^{41}$
Masalah ketidakadilan yang dijumpai dalam hal kesempatan mengakses sumber daya alam dan dalam tindakan eksploitasi lingkungan yang telah menghancurkan sumber daya alam menunjukkan adanya cara hidup dan cara bertindak manusia yang tidak baik. Seperti kita ketahui, perihal baik-buruknya manusia sebagai manusia merupakan ranah moral. Menurut Frans Magnis-Suseno, moral adalah ajaran-ajaran, wejangan-wejangan, kotbah-kotbah, kumpulan peraturan dan ketetapan entah lisan atau tertulis tentang bagaimana manusia harus hidup dan bertindak agar ia menjadi manusia yang baik. ${ }^{42}$ Sedangkan etika -menurut Magnis- dapat dipahami sebagai filsafat atau pemikiran kritis dan mendasar tentang ajaran-ajaran dan pandangan-pandangan moral. Etika memberikan orientasi pada manusia agar ia tidak hidup dengan cara ikut-ikutan saja terhadap pelbagai pihak yang mau menetapkan bagaimana seseorang harus hidup, melainkan agar orang itu mengerti sendiri mengapa dan bagaimana ia harus bersikap. Dengan menyaksikan ketidakadilan dalam bentuk ketidakmerataan akses terhadapa sumber daya alam dan tindakan mengeksploitasi lingkungan yang merusakkan sumber daya alam, FABC memandang isu ekologis merupakan masalah etis dan moral.

Terkait dengan masalah moral, FABC mempunyai visi tentang kehidupan yang holistik (bdk. FABC VI 1995) dan mengedepankan budaya hidup integral (bdk. FABC VIII 2004). Kehidupan yang diidamkan ini merupakan hasil dari pengembangan manusia yang seutuhnya bermartabat, yakni pengembangan otentik setiap dan seluruh manusia untuk mengalami harmoni dan kedamaian batin serta memasukkan unsur etis ke dalam seluruh ciptaan. 


\section{Masalah Ekologis Bercorak Religius}

Dalam hal kehidupan beriman, FABC antara lain menyatakan bahwa dalam upaya semakin menghidupi Ekaristi di Asia terdapat dua hal pokok yang harus selalu ditumbuhkembangkan, yakni iman ekaristis yang hidup dan perayaan ekaristis yang hidup. ${ }^{43}$ Persekutuan dengan Yesus dalam Ekaristi akan memperbarui keterlibatan umat beriman dengan beraneka realitas kehidupan di tengah dunia dan memberi bentuk hidup Kristiani di dalamnya. ${ }^{44}$

Hidup umat Kristiani yang senantiasa diperbarui melalui Ekaristi mencakup pula merayakan rahmat ciptaan dalam dunia yang tidak adil. ${ }^{45}$ Di sini, jalinan hubungan manusia dengan lingkungan diangkat dalam terang iman; rahmat ciptaan dari Allah harus dirayakan oleh umat beriman antara lain dengan memelihara keutuhan ciptaan. Sikap tidak hormat kepada ciptaan akan membawa kepada kehancuran dan kematian. Ciptaan barulah sungguh menjadi tanda hidup dan cinta Pencipta bila kita memiliki kesadaran akan keberadaan ciptaan sebagai karunia ilahi. Para Uskup melihat bahwa wujud kepedulian yang mendesak bagi Gereja-Gereja Kristen adalah membawa pelayanan terhadap ciptaan ke dalam inti spiritualitas dan kemuridan Kristen.

Kita juga dapat mengingat kembali bahwa sedari awal FABC telah mengajukan evangelisasi baru sebagai sarana yang hendak ditempuh guna menggapai visinya, yakni Gereja di Asia menuju sebuah "cara baru menggereja" (a new way of being church). Evangelisasi baru tersebut hendak mencakup seluruh ciptaan dan memberikan tekanan kepada karakter moral dan religius dari ciptaan Allah. ${ }^{46}$
Di satu sisi, FABC memandang perlu untuk menggagas suatu refleksi teologis tentang misteri dan kebenaran ciptaan Allah, dan tentang tanggung jawab moral dan etis kita sehubungan dengan lingkungan. Di sisi lain, bangsa Asia sendiri selama berabad-abad telah ditandai dengan ikatan kekeluargaan yang erat, gaya hidup yang ugahari serta keterikatan mendasar dengan alam. ${ }^{47}$ Dalam menghayati budaya dan hidup rohaninya, masyarakat Asia berhubungan erat dengan alam dan lingkungan di sekitarnya. Oleh karena itu FABC memandang perlu berdialog dengan kebudayaan-kebudayaan dan tradisi-tadisi besar di Asia sebagai sumber-sumber realitas Asia. Dialog dengan budaya, agama dan kepercayaan lokal Asia dipandang perlu ditempuh sebagai salah satu tahapan dalam proses membangun suatu spiritualitas dan teologi tentang ciptaan dan lingkungan. Sebuah upaya membangun teologi tentang ciptaan telah dilaksanakan oleh para teolog OTC FABC di tahun 2012. Sebagai hasilnya, mereka mengajukan empat kepedulian teologis terkait dengan ciptaan, yakni kepedulian akan pelayanan, keadilan dan amal kasih, relasi yang komunal, dan kepedulian akan kontinuitas.

Terkait dengan isu ekologis, upaya FABC untuk berdialog dengan mereka yang berkeyakinan lain terjadi antara lain manakala FABC turut memperhatikan pandangan-pandangan agama-agama dan budaya dalam mengawali refleksi mereka. ${ }^{48}$ Sejatinya agama merupakan elemen terdalam dari budaya. ${ }^{49}$ Jadi, berdialog dengan agama berarti pula mengadakan dialog dengan budaya. Hasil refleksi FABC tersebut akan dibahas dalam dua poin orientasi ekologis FABC di bawah ini. 


\section{Tanggung Jawab dan Harmoni demi Keu- tuhan Ciptaan}

Dalam refleksi iman tentang perubahan iklim, FABC -melalui Unit Kerja Perubahan Iklim (CCD $)^{50}$ melihat bahwa dunia yang harmoni dan indah (Kej 1:1-31) telah dirusak oleh dosa manusia, yakni dalam bentuk kesombongan diri, mementingkan diri dan sifat tamak. Situasi kedosaan ini mengganggu harmoni yang telah tercipta (bdk. Kej 3:1-7; 4:1-16; 6:5-8; 11:1-9). Pemulihan harmoni dan kedamaian terjadi melalui Yesus dengan menyembuhkan semua relasi yang telah rusak sebagai buah-buah dosa.

Berkat pemahaman akan ciptaan, penebusan, dan sejarah manusia yang diterangi oleh iman akan Yesus Tuhan dan Penyelamat inilah FABC melihat dimensi-dimensi perubahan iklim dengan lebih mendalam, kedosaan yang menjadi penyebabnya, dimensi religius dan etis yang menjadi cakupannya dan ancaman yang ditimbulkannya bagi semua umat manusia.

FABC memandang tugas mendasar Gereja di Asia adalah untuk menyerukan pertobatan yang radikal, memajukan gaya hidup alternatif, yakni budaya baru yang menghormati alam, yang sabar dan tenang, yang berpengharapan dan gembira; budaya baru yang menghormati alam dengan pengembangan lestari, memelihara harmoni dan keutuhan ciptaan. ${ }^{51}$

\section{Pertumbuhan Manusiawi yang Holistik, Budaya Hidup Integral, dan Spiritualitas Penatalayanan Ciptaan}

Orientasi ekologis FABC bermuara pada dua buah gagasan untuk melaksanakan tanggung jawab pengembangan lestari, memelihara harmoni dan keutuhan ciptaan.
Gagasan tersebut adalah: (i) mengupayakan pertumbuhan manusiawi yang holistik dan budaya hidup integral; (ii) mengembangkan spiritualitas penatalayanan ciptaan.

\section{Pertumbuhan Manusiawi yang Holistik dan Budaya Hidup Integral}

Visi kehidupan yang holistik mengemuka dalam refleksi para Uskup saat Sidang Paripurna VI tahun 1995 yang bertemakan menjadi murid Kristus di Asia zaman sekarang. Sedangkan gagasan mengedepankan budaya hidup integral lahir dalam refleksi para Uskup saat sidang Paripurna VIII tahun 2004 yang membahas tentang keluarga. Dalam kedua sidang ini, pertumbuhan manusiawi yang holistik dan budaya hidup integral di tempatkan dalam dimensi misioner Gereja. FABC menerjemahkan misi menjadi murid Kristus dengan cara berbakti kepada kehidupan. Sedangkan upaya pembaruan Gereja dipandang FABC sebagai suatu misi kasih dan pelayanan. Refleksi para Uskup pada dimensi misioner ini menghasilkan visi kehidupan yang holistik dan budaya hidup integral.

Salah satu kenyataan di Asia yang disaksikan dalam Sidang Paripurna VI adalah "bom isu ekologi." Masalah lingkungan hidup, bersama dengan masalah keluarga Asia, kaum wanita dan anak-anak, kaum muda, dan mereka yang tercabut dari akar-akar mereka dalam masyarakat merupakan lima bidang yang memerlukan perhatian pastoral istimewa. Dalam sidang ini dengan tegas disebutkan bahwa para Uskup mengedepankan: kehidupan yang utuh dan bermartabat; kehidupan yang ditandai dengan belas kasihan terhadap rakyat banyak, khususnya kaum miskin dan serba kekurangan; kehidupan dalam solidaritas dengan tiap 
bentuk kehidupan dan perhatian yang peka terhadap alam semesta. ${ }^{52}$

Bagi para Uskup, peran serta untuk membentuk dan mewujudkan visi kehidupan holistik di Asia, bersama-sama dengan bangsa-bangsa Asia, dan demi rakyat Asia hendak ditempuh melalui kehidupan mengikuti jejak Yesus. ${ }^{53}$ Misi Yesus memberi kehidupan yang melimpah kepada manusia (bdk. Yoh 10:10). Misi Yesus ini sekaligus melukiskan perutusan Yesus mewartakan dan memulai Kerajaan Allah (bdk. mrk 1:15). Dengan demikian Yesus mengajarkan arti kehidupan dalam Kerajaan Allah, yakni hidup dalam persekutuan dengan Allah dan dengan sesama, serta senantiasa diteguhkan dan diremajakan oleh Roh Kudus, "Tuhan, Pemberi Kehidupan.”54

Sementara itu, para peserta Sidang paripurna VIII mengungkapkan bahwa keluarga-keluarga di Asia tetap dapat menemukan kebahagiaan mereka meski berhadapan dengan kesengsaraan dan kemiskinan yang tak teratasi. Dalam refleksi teologis-pastoral yang dilakukan terkait realitas ini, para Uskup tiba pada sebuah spiritualitas yang dibutuhkan keluarga-keluarga umat beriman di Asia, yakni budaya hidup integral. Keluarga-keluarga umat beriman di Asia, menurut para Uskup, membutuhkan spiritualitas ini dalam mewujudkan identitas dan menunaikan misi mereka.

\section{Spiritualitas Penatalayanan Ciptaan}

Kantor untuk Urusan Teologi atau Office of Theological Concerns (OTC) FABC sejak tahun 2012 telah mengeksplorasi suatu pendekatan Kristiani di Asia dalam menghadapi masalah ekologi. Hasil refleksi teologis pastoral mereka kemudian dipublikasikan di bulan Juni tahun 2015 dalam sebuah dokumen berjudul "Menuju Penatalayanan
Ciptaan yang Bertanggung Jawab: Sebuah Pendekatan Kristiani Asia”. Dokumen ini memuat kenyataan di Asia berkenaan dengan ekologi dan dampaknya serta khazanah pandangan beberapa tradisi besar di Asia. Sebagai buah refleksi, OTC merekomendasikan pengembangan spiritualitas penatalayanan ciptaan sebagai wujud Gereja di Asia dapat secara nyata berkiprah melindungi karya ciptaan Allah dan memajukan semangat pelayanan yang bertanggung jawab.

Setelah menyaksikan biodiversitas dan ekosistem Asia yang luar biasa sebagai rahmat Allah yang besar dan memperhatikan masukan ilmu pengetahuan terhadap masalah ekologi, para teolog OTC kemudian mengarahkan pandangan mereka kepada sumber-sumber Asia, yakni beraneka tradisi religius dan budaya yang ada di Asia, seperti: Islam, Budhisme, Konfusianisme dan Taoisme, Shintoisme, eko-spiritualitas pribumi dan spiritualitas ekofeminis.

Barulah setelahnya, para teolog mulai mencari suatu pendekatan Kristiani di Asia dalam menghadapi masalah ekologi. Pencarian ini dimaksudkan untuk membangun suatu teologi tentang ciptaan. Berangkat dari refleksi biblis seperti teks Kejadian 1:11-2:3 dan 2:5-3:24 menemukan beberapa gagasan mengenai awal mula penciptaan, penciptaan manusia, kebaikan dalam ciptaan, misi manusia sebagai pelayaan ciptaan, tentang bekerja dan beristirahat, serta kejatuhan dan janji penebusan manusia. Selanjutnya para teolog melengkapi pencarian mereka dengan memperhatikan beberapa dimensi teologis lainnya, seperti teologi trinitaris, kristologis, pneumatologis, kosmis, antropologis dan etis.

Hasil studi para teolog tersebut disampaikan dalam empat kepedulian teologis, yakni: kepedulian tentang pentingnya 
penatalayanan terhadap sumber-sumber dan karunia yang telah diberikan Allah melalui penciptaan-Nya; tentang pentingnya keadilan dan amal kasih; tentang relasi komunal antara alam dan manusia; dan tentang kontinuitas ciptaan. Akhirnya, para teolog OTC FABC merekomendasikan agar iman kristiani memajukan suatu teologi penatalayanan ciptaan yang bertanggung jawab dan menemukan kembali spiritualitas yang melihat ciptaan sebagai karunia Allah untuk dihargai.

\section{PENUTUP}

Gagasan besar FABC antara lain adalah tentang a new way of being church (FABC III dan IV) di Asia. Jalannya adalah melalui evangelisasi baru (FABC II dan X). Tujuan di balik gagasan ini adalah untuk menjadikan Gereja di Asia sebagai persekutuan-persekutuan umat beriman yang sejati (FABC II), yang sungguh-sungguh incarnate dan in $d i$ alogue (FABC I) dalam masyarakat tempat ia berada. Evangelisasi baru mencakup $d i$ alog rangkap tiga (FABC I) yang dilakukan terutama oleh Gereja-Gereja lokal (FABC III dan VII) beserta kaum awam (FABC IV) dan keluarga-keluarga (FABC VIII dan XI) di dalamnya.

FABC sedari awal pendiriannya telah berkomitmen untuk menjadikan persekutuan-persekutuan umat Katolik Asia in dialogue dengan kenyataan di medan hidupnya, incarnate dalam masyarakat tempat mereka berada, dan inculturated dengan tradisi-tradisi kultural-religius. Berikut ini adalah beberapa catatan untuk diperhatikan. Pertama, ada banyak gagasan, anjuran hingga petunjuk praktis yang dirumuskan FABC sebagai tanggapan atas isu ekologis di Asia. Semua temuan ini masih perlu disosialisasikan ke tingkat regional hingga lokal. FABC dapat memanfaatkan agensi-agensi yang ada dalam federasi untuk menyelenggarakan kegiatan sosialisasi seperti workshop dan seminar. Kegiatan-kegiatan semacam ini dapat digalakkan melalui kerja sama antara agensi-agensi FABC dengan komisi-komisi dalam konferensi episkopal. Kedua, FABC masih kesulitan mengetahui manfaat buah-buah pemikirannya di tingkat akar rumput. Sebaliknya, kesulitan juga dialami FABC saat hendak menggali sumbangsih gagasan dari pihak akar rumput. Di sini, kerja sama dinamis antara FABC dengan konferensi-konferensi regional dan nasional menjadi dapat menjadi solusi.

Ketiga, dari pihak konferensi-konferensi lokal dan regional. Seperti kita ketahui, keputusan-keputusan FABC sebagai sebuah asosiasi sukarela bersifat tidak mengikat. Namun kita menyaksikan bahwa hasil kerja FABC ini merupakan perwujudan salah satu fungsi federasi untuk menyediakan pelayanan bagi konferensi-konferensi episkopal di Asia dengan tujuan membantu mereka memahami dengan lebih baik kebutuhan-kebutuhan umat Allah. Oleh karena itu, masing-masing konferensi episkopal perlu menanggapinya antara lain dengan mendaratkannya dan menerjemahkannya secara kreatif bagi Gereja lokal, sampai ke tingkat praksis. Tentu saja hal ini dilakukan dengan penyesuaian terhadap situasi dan kebutuhan setempat. Pelaksanaan buahbuah refleksi FABC di tingkat lokal juga menjadi perwujudan kerja sama dan tanggung jawab kolegial konferensi-konferensi waligereja yang pada gilirannya nanti dapat pula memberikan sumbangsih bagi refleksi bersama di kemudian hari. 


\section{CATATAN AKHIR}

1 Ada lima belas dokumen yang akan diuraikan di sini, yakni satu dokumen hasil pertemuan perdana para Uskup Asia di tahun 1970, sebelas dokumen hasil semua sidang paripurna FABC sejauh ini, dua dokumen hasil seminar FABC tentang perubahan iklim, dan satu dokumen Kantor Urusan Teologi (Office of Theological Concerns/OTC). Kompilasi dokumen-dokumen FABC dari tahun 1970-2016 termuat dalam enam volume buku For All The Peoples of Asia, yakni Gaudencio Rosales dan Catalino Arévalo (ed.), For All the Peoples of Asia: Federation of Asian Bishops' Conferences Documents from 1970 to 1991 (Quezon City: Claretian Publications, 1992); Franz-Josef Eilers (ed.), For All the Peoples of Asia: Federation of Asian Bishops' Conferences Documents from 1992 to 1996, vol. 2 (Quezon City: Claretian Publications, 1997); Franz-Josef Eilers (ed.), For All the Peoples of Asia: Federation of Asian Bishops' Conferences Documents from 1997 to 2001, vol. 3 (Quezon City: Claretian Publications, 2002); Franz-Josef Eilers (ed.), For All the Peoples of Asia: Federation of Asian Bishops' Conferences Documents from 2002 to 2006, vol. 4 (Quezon City: Claretian Publications, 2007), Vimal Tirimanna (ed.), For All the Peoples of Asia: Federation of Asian Bishops' Conferences Documents from 2007 to 2012, vol. 5 (Quezon City: Claretian Publications, 2014); Vimal Tirimanna (ed.), For All the Peoples of Asia: Federation of Asian Bishops' Conferences Documents from 2012 to 2016, vol. 6 (Quezon City: Claretian Publications, 2017).Enam buku ini selanjutnya akan dirujuk sebagai FAPA I, FAPA II, FAPA III, FAPA IV, FAPA V, dan FAPA VI. ${ }^{2}$ ABM no.9, dalam FAPA I, 4.

FABC III no. 8.1, dalam FAPA I, 57.

ABM no. 5, 10, dalam FAPA I, 4

FABC I no. 19, dalam FAPA I, 15.

FABC I, no. 19, dalam FAPA I, 15; FABC V no. 2.2.1, dalam FAPA I, 276.

FAPA VII no. II.A, dalam FAPA III, 6.

8 "Lineamenta" no. 5-6, dalam Seri Dokumen FABC No. 4: Dokumen Seputar Sinode Para Uskup Bagi Asia Tahun 1998, 342-346.

9 "Lineamenta" no. 6, 345

10 "Lineamenta" no. 5, 342-344.

11 GS art. 53.

12 FABC/TAC, "Theses on the Local Church" no. B.I.2, dalam Sprouts of Theology from The Asian Soil: Collection of TAC and OTC Documents [1987-2007] (Claretian Publications, Bangalore, 2007), 24-26. Selanjutnya akan dikutip sebagai Sprouts.

13 James Thoppil, Toward An Asian Ecclesiology (Oriens Publications, Shillong, 2005), 31.

14 ABM no. 13 dalam FAPA I, 4.

15 ABM/Resolutions no.1, dalam FAPA I, 8.

16 Konferensi Episkopal yang menyusul bergabung, yakni: India - CBCI, India - Syro-Malabar, India - Syro-Malankara, India - Ritus Latin, Kazakhstan, Taiwan, dan Timor Leste. Anggota luar biasa yang menyusul bergabung adalah Mongolia, Nepal, Kyrgyzstan, Tajikistan, Turkmenistan, dan Uzbekistan; tersedia dari http:// www.fabc.org/mem.html, diakses 21 Desember 2017.

17 Bagian tulisan ini bersumber dari http://www.fabc.org/ about.html; diakses 21 Desember 2017.

18 Bagian tulisan ini bersumber dari tulisan Felix Winfred, "The Federation of Asian Bishops' Conferences (FABC): Orientations, Challenges and Impact" dalam FAPA I, xxiii-xxx.

19 FABC III/Resolutions III, dalam FAPA I, 63. Sepuluh ta- hun setelah berdiri, FABC mulai menyoroti dan secara jelas menyebutkan bahwa Asia berpotensi mengalami masalah ekologis di Asia.

20 FABC V no. 2.2.1, dalam FAPA I, 276-277.

$21 \quad$ FABC V no. 2.3.4 dalam FAPA I, 278.

22 FABC V no. 2.1-2.2 dalam FAPA I, 275-277.

23 BIRA IV/11 no. 13 dalam FAPA I, 320.

24 BIRA IV/11 Pastoral Recomendations no.2 dalam FAPA I, 323.

25 BIRA IV/12 no.33 dalam FAPA I, 330.

26 BIRA IV/11 Pastoral Recomendations no.2 dalam FAPA I, 323.

27 FABC VI no. 15.4 dalam FAPA II, 11. Selain ekologi, area pastoral besar lainnya adalah: keluarga, kaum perempuan dan anak perempuan, kaum muda, kaum pengungsi dan migran (FABC VI no.15, dalam FAPA II, 1012). Beragam bentuk krisis ekologi dan lingkungan dapat dilihat pada FABC/TAC, "Perspektif Umat Kristiani Asia Tentang Harmoni" no. 1,3 dalam FAPA II, 237-238.

28 FABC VI no. 10 dalam FAPA II,5.

29 FABC VI no. 15 dalam FAPA II,10-11.

$30 \quad$ FABC VII no. II.D dalam FAPA III, 7.

31 FABC VII Part II dalam FAPA III, 6-8.

32 FABC VIII no.52 dalam FAPA IV, 18.

$33 \quad$ FABC Papers 129 no. C. 7. $i$.

$34 \quad$ FABC Papers 129 no. G. 4.7.

$35 \quad$ FABC Papers 138 no. 27.

36 FABC/OTC, "Roh Kudus Tengah Berkarya di Asia Dewasa Ini" no. 2.1.2 dalam FAPA III, 268-269.

37 FABC/TAC, "Perspektif Umat Kristiani Asia Tentang Harmoni" no. 2.2.3 tentang kepedulian ekologi, dalam FAPA II, 251-252.

38 FAPA VI, 32-33.

39 Dokumen hasil kegiatan ini diterbitkan FABC dalam FABC Papers 146.

40 FAPA VI, 195-202

${ }^{41} \quad$ FABC V no. 2.1-2.2, dalam FAPA I, 275-277.

42 Frans Magnis Suseno, Etika Dasar: Masalah-masalah Pokok Filsafat Moral (Kanisius, Yogyakarta, 1987), 1419

$43 \quad$ FABC IX 2009 dalam FAPA V, 11

44 FAPA V, 11

45 FAPA V, 36

46 Evangelisasi baru itu dapat menjadi kredibel dan efektif berkat Roh Kudus yang merupakan Roh Evangelisasi Baru (lih.FAPA V, 78,80-81).

47 FAPA VI, 197-198

48 Kantor Urusan Teologi (OTC) FABC mengawali refeksi mereka mengenai pendekatan Kristiani dalam menanggapi isu ekologi dengan menempatkan sumber-sumber realitas Asia, antara lain posisi tradisi-tradisi besar di Asia (Kristiani, Islam, Budhisme, Konfusianisme, Taoisme, Shintoisme, dan beberapa tradisi religius pribumi) terkait dengan ekologi dan dampaknya. Lihat FABC Papers 146.

49 Lih. Theses on Interreligious Dialogue: An Essay in Pastoral Theological Reflection, Thesis no. 1, dalam Sprouts, 3-5.

50 Lih. "I FABC Climate Change Seminar: Church Respon to the Challenge of Climate Change in Asia: Towards a New Creation," dalam FAPA VI, 187-193.

51 FAPA VI, 190-191.

52 FABC VI no. 10, dalam FAPA II, 5.

53 FABC VI no. 12-14.

$54 \quad$ FABC VI no. 13.1.-13.5 


\section{DAFTAR RUJUKAN}

Eilers, Franz-Josef (ed.). For All the Peoples of Asia: Federation of Asian Bishops' Conferences Documents from 1992 to 1996, vol. 2. Quezon City: Claretian Publications, 1997. . For All the Peoples of Asia: Federation of Asian Bishops' Conferences Documents from 1997-2001, vol. 3. Quezon City: Claretian Publication, 2002.

. For All the Peoples of Asia: Federation of Asian Bishops' Conferences Documents from 2002 to 2006, vol. 4. Quezon City: Claretian Publications, 2007.

Frans Magnis Suseno. Etika Dasar: Masalah-masalah Pokok Filsafat Moral. Yogyakarta: Kanisius, 1987.

Rosales, Gaudencio dan Arévalo, Catalino (ed.). For All the Peoples of Asia: Federation of Asian Bishops' Conferences Documents from 1970 to 1991. Quezon City: Claretian Publications, 1992.
Seri Dokumen FABC No. 4: Dokumen Seputar Sinode Para Uskup Bagi Asia Tahun 1998. diterjemahkan oleh R. Hardawiryana, SJ. Jakarta: Departemen Dokpen KWI, 2000.

Thoppil, James. Toward An Asian Ecclesiology. Shillong: Oriens Publications, 2005.

Tirimanna, CSsR, Vimal (ed.). Sprouts of Theology from The Asian Soil: Collection of TAC and OTC Documents [1987-2007]. Bangalore: Claretian Publications, 2007.

. For All the Peoples of Asia: Federation of Asian Bishops' Conferences Documents from 2007 to 2012, vol. 5. Quezon City: Claretian Publications, 2014.

For All the Peoples of Asia: Federation of Asian Bishops' Conferences Documents from 2012 to 2016, vol. 6. Quezon City: Claretian Publications, 2017.

FABC Papers dapat diakses melalui website www. fabc.org 